\title{
DA'WAH IN RESPONDING TO THE PROBLEMS OF CONTEMPORARY RADICALISM
}

\author{
Arifuddin', Faridah ${ }^{2}$ \\ UIN Alauddin Makassar ${ }^{1}$, IAIM Sinjai ${ }^{2}$ \\ arifuddin.tike@uin-alauddin.ac.id ${ }^{1}$. andifaridah81@ gmail.com $^{2}$
}

\begin{abstract}
This research reveals the solution of Da'wah in addressing the problems of contemporary radicalism that works vigilantly and understands further the causes of radicalism that determine the handling of the problems found. There are several causes of radicalism, namely social factors including economic and political factors, religious factors and psychological factors, these three factors equipped with the presence of the internet which causes the problem of radicalism spread more easily in the community. The da'wah solution carried out for the problem of radicalism is the cooperation between all elements of society by implementing actions according to their respective to their main duties and functions. Da'wah is carried out coolly, accompanied by exemplary, Islam must appear in an attractive, friendly, tolerant, moderate form of preaching that is continuously reformed, the practice of the four pillars of nationality (Pancasila, 1945 Constitution, Bhinneka Tunggal Ika, and NKRI). Besides that, there is a need to improve the quality of human resources and equal justice for the entire community.
\end{abstract}

\section{Keywords: Da'wah Solution; Set of Problems; Contemporary Radicalism}

\section{PRELIMINARY}

Sunday, March 28, 2021, Makassar and its surroundings were shocked by the suicide bombing at the Makassar Cathedral Church, various opinions can be read in various online news media related to this event. From ordinary people to the president conveyed condemnation and condemnation related to the incident.

Quoted in the online media the President of the Republic of Indonesia, Ir.Joko Widodo said that "Terrorism is a crime against humanity that has nothing to do with religion, whatever all religious teachings strongly reject for whatever reason" then the president invites all people to jointly fight terrorism, radicalism contrary to religious values, ancestors as a nation that upholds divine values and upholds the values of diversity. ${ }^{1}$

In a different place, the Dean of the Faculty of Da'wah and Communication at UIN Alauddin Makassar, Firdaus Muhammad stated that:

"I hope for the need to strengthen da'wah literacy in the midst of society by carrying the theme of religious moderation and tolerance. This needs to be done to create peace. This is very necessary to always minimize the potential for violence in the name of religion, let alone terrorists. I think it is the most important

${ }^{1}$ Suara jelata.com, Jokowi Asks the National Police Chief to Completely Investigate the Network of Suicide Bombers in Makassar., accessed Thursday 01 April 2021. 
thing for campus circles to be intensified, because we must really guarantee that the potential for radicalism can be nil on campus. "2

Analyzing the incident, Najahan Musyafak, one of the terrorism observers, spoke up, in this case he stated that the bomb explosion that occurred at around 10.28 WITA could not be separated from previous cases. We can't see that one problem has become a single accident, but we have to prosecute even though today it is not known who (the perpetrator) is, but if we look at the series of events in the month that starting at the beginning of the year there were arrests, including in Surabaya, Medan and then in Makassar. bombing. Personally, they may not be related, they may not know each other, but what unites them is ideology, they are in the same ideology. ${ }^{3}$

Responding to various statements related to this, a member of the South Sulawesi Kamtibmas Dai, Hamka Mahmud expressed his opinion that "from various analyzes made by observers related to the bomb that exploded at the Makassar Cathedral Church, such as the opinion that the terror act was revenge. against several people arrested this past month. This may be the perpetrators are remnants of JI and MIT leaders in the city of Makassar. According to him, this could be an act of revenge, maybe this perpetrator is part of a network that was arrested in 2020 at the Vila Mutiara Makassar housing location. The location of this raid, claimed the lives of two people. Because he resisted when he was arrested by the police. ${ }^{4}$

In the following week, the public was again shocked by the reckless action of a woman in POLRI HQ. In the narration of an online media it is said that acts of terrorism at the National Police Headquarters are not only shocking but also cause concern. Moreover, the action was carried out by a girl who raised a gun and ended with officers shooting until the perpetrator died. ${ }^{5}$

In this case, Najahan Musyafak again expressed his opinion that "what is seen today is a suicide bomber, a suicide bomber. Though; Behind it all there are roles played by women apart from being suicide bombers, for example their role as motivators like the one in Makassar MM convinced YSF and L. There is another role for women as educators as educators and there are women. I gave an example that the process of radicalization to the point of terrorism had started from formal education in radical schools. ${ }^{6}$

Regarding this incident, TB Hasanuddin, a member of the DPR conveyed his assessment of the failed deradicalization program. Hasanuddin in this case expressed his concern because the spreaders of radicalism are now targeting millennials who incidentally are still in the process of finding their identity. In a media, TB Hasanuddin stated that "Ironically, many millennials are influenced by powerful provocateurs in the name of religion. Moving young people to become brides and bombers with the promise

\footnotetext{
${ }^{2}$ Firdaus Muhammad, Dean of FDK UIN Alauddin Condemns Acts of Terrorism as well as Realizes the Importance of Religious Moderation, SyiarMedia.id accessed Thursday 1 April 2021.

${ }^{3}$ Sindonews.com, Bomb Explosion at Makassar Cathedral, Observer: Message of Solidarity for Terrorist Networks., accessed Thursday 1 April 2021.

${ }^{4}$ Hamka Mahmud, Study of Dai Kamtibmas, Sadistic Makassar Bombing Perpetrator, Sunday, March 28, 2021.

${ }^{5}$ Najahan Musyafak, Women in Terrorism Vortex, From Educator to Executor, Oke news, accessed Thursday 01 April 2021.

${ }^{6}$ Najahan Musyafak, Woman in Terrorism Vortex, From Educator to Executor, Oke news, accessed on Thursday 01 April 2021
} 
of heaven. While the provocateurs sit quietly enjoying the life of the world. Why don't they just set an example for entering heaven."

What is interesting from the various statements related to the incident is the unity of opinion that the terrorist acts carried out were due to radicalism. We can see the close relationship between radicalism and terrorism in the words of Brian Michael Jerking "Terrorists do not fall from the sky, they come from a set of beliefs that are considered strong. They are radicals, and then become terrorists. ${ }^{8}$

Knowledge and understanding of this makes the issue of radicalism increasingly a trend and makes almost every community uneasy, its presence has become national and even global. However, this issue seems to be led or addressed to one religious understanding, namely Islam. And the issue of radical Islam has become a political problem for nations. ${ }^{9}$

There are various reasons that make public opinion mentionthat extreme actions as an effect of radicalism include the fact that various acts of violence such as demonstrations, protests and terrorism, are in reality partly carried out by Muslim groups affiliated with radical Islamic organizations. So that criticism is often heard stating that Islam is suspected as a religion that brings peace and safety, but why do some of its adherents become radical and are willing to carry out acts of radicalism and terrorism? ${ }^{10}$

The spread of terrorism today which is always associated with issues of radicalism raises questions about the role of da'wah in the spread of Islamic teachings as well as in anticipating the notion of radicalism which is increasingly disturbing the community. Islamic teachings that contain a missionrahmatan lil alaaminas stated in QS. AlAnbiya/21:107;

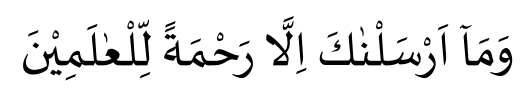

The translation:

"And We have not sent You (Muhammad) but to be a mercy for the worlds."11

This verse very clearly describes that the Messenger of Allah as the messenger of Islam was sent to this world as a mercy from Allah swt. In the Indonesian dictionary, Rahmat in this case means compassion. ${ }^{12}$ So that it can be more understood that Islam is a religion whose teachings contain compassion for the universe and all its contents.

These descriptions increasingly raise questions about the gap between the facts about the phenomenon of radicalism which is allegedly carried out by Muslims, while it is understood together that Islamic teachings are actually teachings that carry a mission of mercy and peace that should be applied by its adherents.

Based on the descriptions of the issue of radicalism that have been described previously, the author will try to further examine the definition, causes and development

\footnotetext{
${ }^{7}$ TB Hasanuddin, DPR: Deradicalization Operations in Indonesia Failed, Even though the Budget is Trillion, Merdeka.com. accessed Thursday 1 April 2021.

${ }^{8}$ Iman Fauzi Ghifari, Radicalism on the Internet, Religious: Journal of Religion and CrossCulturalism 1, 2, p.125. (March 2017) accessed Friday 02 April 2021.

${ }^{9}$ M. Sidi Ritaudin, Kalam: Journal of Religious Studies and Islamic Thought, State Radicalism and Power from a Global Political Perspective, accessed March 25, 2021.

${ }^{10}$ Nurjannah, Factors Triggering the Emergence of Islamic Radicalism in the Name of Da'wah, Journal of Da'wah, Vol. XIV, No. 2 of 2013, Accessed Friday, April 1, 2021.

${ }^{11} \mathrm{Al}-\mathrm{Qur}$ 'an and Translation, p.331.

${ }^{12}$ Big Indonesian Language Dictionary (KBBI) Online, Accessed Friday 16 April 2021.
} 
of radicalism, as well as the solution to da'wah in overcoming radicalism today, especially in Indonesia, which has a Muslim majority population (Muslim).

\section{THEORETICAL STUDY}

\section{A. Da'wah}

Islam is a teaching of truth, namely inviting people in ways that are pleasing to Allah swt.13The method used to convey the teachings of truth in Islam is called da'wah. This da'wah is an obligation for Muslims because with the da'wah the message of Islam as rahmatan lilalamin can be disseminated.

Da'wah is an activity to invite mankind to the path of truth in accordance with the Shari'a that has been determined by Allah swt in the Qur'an and Hadith. The law of preaching is obligatory, where the command of da'wah can be found in several verses of the Koran as stated in the QS. Ali-Imran verse 104:

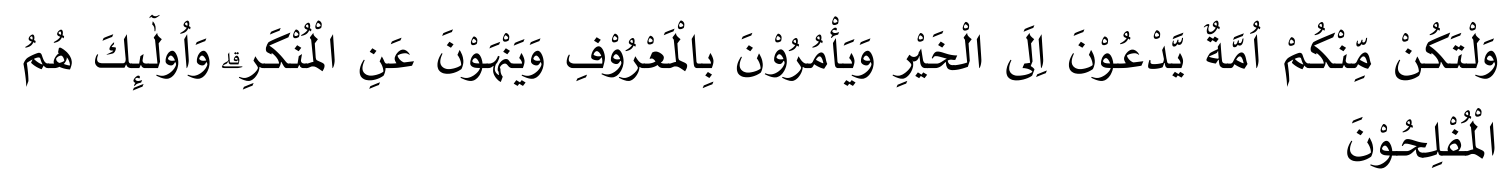

The translation:

"And let there be among you a group of people who call to righteousness, enjoin the right and forbid what is evil, they are the lucky ones. "14

This verse expressly conveys the command to preach and is further clarified by the hadith of the Prophet, namely:

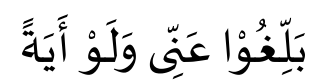

Meaning:

"Convey from me (Rasulullah saw) even if only one verse." 15

Based on these verses and hadiths, it is very clearly understood that the obligation to preach is an obligation that cannot be avoided by every Muslim, because with the implementation of da'wah means that the message of Islam which is a blessing for the universe can be felt and enjoyed by all creatures in this universe. ${ }^{16}$

Associated with its form, da'wah is also called Islamic communication which has several characteristicsa. elements such as dai, media (wasilah), method (uslub) material (mawdu"), target (mad'u) and purpose of da'wah. ${ }^{17}$ Da'wah as Islamic communication, in this case it is understood that da'wah activities are a form of communication carried out by dai as communicators and mad'u as communicants, in particular the message conveyed in da'wah is more specifically discussing the teachings of Islam. The implementation of

13 Arifuddin Tike, http://journal.uin-alauddin.ac.id/index.php/Al-Khitabah/article/view/2575, accessed Saturday 03 April 2021.

${ }^{14}$ The Qur'an and its translation, H.63

${ }^{15}$ Abu 'Isa Muhammad bin 'Isa bin Surah Attirmidhi, Sunan Al-Turmudzi, Juz IV (Semarang: Toha Putra, tt), p. 147.

${ }^{16}$ Faridah, Analysis of the Implementation of Dai's Example in the Effectiveness of Da'wah in the Contemporary Era, MIMBAR Volume 1 Number 1, 2015, p. 94.

${ }^{17}$ Acep Aripudin, Development of Da'wah Methods, Jakarta: Rajagrafindo Persada, 2011, p.1. 
da'wah in this study of communication can be in the form of verbal communication in the form of oral communication or in the form of non-verbal language in the form of behavior or action.

Substantially philosophically, da'wah is engineering and engineering to change all forms of worship to other than Allah to the belief in monotheism, changing all types of unequal life towards a flat life filled with inner peace and outward welfare based on Islamic values. ${ }^{18}$ From this we can understand that da'wah is an action that has the aim of changing or wanting change, in the sense that the essence of da'wah is an effort to change humans, both individuals and society, from a bad situation to a better situation. ${ }^{19}$

Today, the concept of the effectiveness of da'wah is getting question marks. In its struggle to realize Islam as a mercy for the universe, da'wah is increasingly finding formidable challenges that require thought, energy and various resources in finding solutions. The various problems of the ummah both on the scale of individuals, families, communities, nations and even the world are part of the responsibility of da'wah so that these various problems cannot escape the thoughts of da'wah activists.

The problem with the people today that consumes the most public energy apart from the level of poverty and the Covid-19 pandemic that is still hitting is the issue of radicalism. Various extreme actions carried out by a group of people will generally be directed and directed at one concept, namely radicalism. One of the extreme acts that are most often associated with the issue of radicalism is terrorism.

Dedi Prasetyo in Imam Fauzi in this case states that Radicalism has a very strong relationship with terrorism, both of which are acts of violence or threats to human life. ${ }^{20}$ Ahmad Fuad Fanani in Imam Fauzi stated that in general, terrorists who commit a lot of destructive actions and suicide bombings have a radical understanding of various things, especially religious matters. ${ }^{21}$ Meanwhile, according to Hendar Riyadi in Imam Fauzi Ghifari, Radicalism in this case is an understanding or violence in religion and in the name of religion which is still quite worrying. ${ }^{22}$

In contrast to this opinion, Ahmad Syafii Maarif stated that radicalism is more related to the way one's religious expression is expressed in an attitude model, while terrorism clearly includes criminal acts for political purposes. Radicalism is more associated with internal religious problems, while terrorism is a global phenomenon that requires global action as well. But on the other hand, radicalism can sometimes turn into terrorism, although not all of them and forever will be. but actually radicalism is a stageor one step before terrorism. So it can be said that radicalism is not exactly the same and also cannot be equated with terrorism. ${ }^{23}$

According to Yusuf Qardhawi in Arifuddin Tike, Radicalism is a form of excessive attitude possessed by someone in religion, there is a discrepancy between belief and behavior, between what should be and reality, between religion and politics, between

\footnotetext{
${ }^{18}$ Asep Muhyidin and Agus Ahmad Safei, Methods of Da'wah Development, Bandung: Setia Pustaka, 2002, p.29.

${ }^{19}$ M. Munir and Wahyu Ilaihi, Da'wah Management, Jakarta: Kencana, 2006, p. 18.

${ }^{20}$ Iman Fauzi Ghifari, Radicalism on the Internet, Religious: Journal of Religion and Cross Culture 1, 2 (March 2017), p.125., accessed Friday 02 April 2021.

${ }^{21}$ Iman Fauzi Ghifari, Radicalism on the Internet, Religious, p.125.

${ }^{22}$ Iman Fauzi Ghifari, Radicalism on the Internet, Religious., p.123.

${ }^{23}$ Iman Fauzi Ghifari, Radicalism on the Internet, Religious., p.125.
} 
words and actions, between wishful thinking and reality. implemented, as well as between the law required by Allah swt with the product of human law itself. ${ }^{24}$

\section{B. Radicalism}

Etymologically, radicalism comes from the word radix which means root (tree). Radical thinking is thinking in more detail and depth, when it is associated with religion, radical thinking is thinking deeply about religious understanding.

Radicalism is the view/way of thinking of someone who wants quality improvement, improvement, and peace in a multidimensional environment, so that all levels of society can live in harmony and peace. ${ }^{25}$

Radicalism in this case can also be known, understood and analyzed from two perspectives, namely social and religious perspectives. From a social perspective, radicalism is considered as an understanding that is believed by individuals or groups who want to make fundamental changes to the prevailing social order by prioritizing confrontational attitudes in the form of intimidation, suppression and violence. As for the Islamic perspective, radicalism is an understanding based on fanatical ideological beliefs about the values they are fighting for to replace the existing value order and system with Islam in a formalistic manner and sometimes use violence to achieve its goals. ${ }^{26}$

Faiz Yunus cites Tarmizi Taher's comments about radicalism with positive meanings, namely tajdid (renewal) and islah (improvement, a spirit of change towards the good of the nation and state). ${ }^{27}$

Radicalism is an understanding that requires changes and changes in a community system in all aspects of people's lives by using very ideal thinking by using plans.

Talking about religious understanding, this is very closely related to the role of da'wah so that between da'wah and the issue of radicalism has a very close relationship or relationship. Da'wah in the face of radicalism has a strategic role in conveying Islamic teachings to the entire community. Through da'wah, people's understanding of the values of Islamic teachings that are tolerant, peace-loving, and rahmatan lil alamin will be more evenly distributed in society so that justification for their own opinions that tend to lead to radicalism will be easily eliminated in social life.

Islam as a religious teaching that brings mercy to the whole world and has recently been stigmatized as a religion and a religious community with violence, but as a da'wah interpreter, he must consistently preach tolerantly as a real effort to get rid of that stigma. With a tolerant da'wah, Muslims in the future will be able to be felt by all mankind as a religious teaching that is rahmatan lilalamin as the duty of the prophet Muhammad saw. As a prophet who brings mercy to the whole world.

${ }^{24}$ Arifuddin Tike, Da'wah and Contemporary Issues, Scientific Forum, Sunday 11 April 2021.

${ }^{25}$ A Faiz Yunus, Liberalism and Terrorism: Its Influence on Islam, Journal of the Study of the Qur'an; Vol. 13 , No. I , Year. 2017 Building a Tradition of Qur'anic Thinking doi.org/10.21009/JSQ.013.1.06, p. 81

${ }^{26}$ Najahan Musyafak and Lulu Choirun Nisa, Community Resilience Against Radicalism: Peaceful Actions and Religious Conflict, Semarang; Lawwana, 2020, p.29.

${ }^{27} \mathrm{~A}$. Faiz Yunus, Radicalism, Liberalism and Terrorism: Their Influence on Islam, Journal of the Study of the Qur'an; Vol. 13 , No. I , Year. 2017 Building a Tradition of Qur'anic Thinking doi.org/10.21009/JSQ.013.1.06 76 Journal of Al-Quran Studies, P-ISSN: 0126-1648, E-ISSN: 2239-2614. 


\section{III.RESEARCH METHOLOGY}

This research is descriptive qualitative, namely analyzing and describing the reality of society in relation to the phenomenon of pajam radicalism. The research approach, using a sociological approach, a psychological approach, a communication approach, research data sources. Data collection techniques using observation and documentation techniques. The author observes the phenomena that occur and conducts searches on news and articles related to the issue of contemporary radicalism. While the data analysis that the author uses is the interactive model of Miles and Huberman, which is a data analysis technique that is carried out at the time of data collection and after data collection, namely in a certain period (Sugiono: 246) there are several steps taken in this data analysis technique, namely: a) Data Reduction, namely an analytical effort by summarizing and selecting basic data and focusing on important data and looking for the most important and relevant themes related to da'wah solutions in addressing the problems of contemporary radicalism; b) Display or data presentation, namely the efforts of researchers in presenting data in the form of charts, brief descriptions and the like, this effort is a follow-up step of data reduction; and c) Verification or conclusion is an attempt to conclude the data after it has been patterned, focused and arranged systematically in the form of a narrative brief descriptions and the like, this effort is the next step of data reduction; and c) Verification or conclusion is an attempt to conclude the data after it has been patterned, focused and arranged systematically in the form of a narrative brief descriptions and the like, this effort is the next step of data reduction; and c) Verification or conclusion is an attempt to conclude the data after it has been patterned, focused and arranged systematically in the form of a narrative.

\section{RESEARCH RESULTS AND DISCUSSION}

\section{A. Causes of the Emergence of Radical Understanding and Its Development}

The current global political reality has been responded to by discrediting Islam, this has triggered the Islamic Fundamentalists to react strongly by presenting themselves as a radical movement, which among others displays symbols of anti-US, Jews and their allies. Some Muslims gave a disproportionate reaction, such as the movement to boycott commodities from American and Jewish products. They insist on Islamic values, while providing "resistance" that is anarchic in nature. The attitude of some Muslims like this was later identified as a radical movement. The emergence of this radical movement in the end gave rise to a discourse of radicalism which is understood as a hard-line Islamic school not only in Indonesia, but globally, which has spread throughout the world. ${ }^{28}$

In the global arena, some observers of Islam and the Middle East suspect that the motives of the radicalism movement are the antithesis of political, economic, power, and civilized arrogance. The paradox of Islamic radicalism with activists carrying the ideas of secularism, pluralism, and religious liberalism has been going on for a long time and has no end. ${ }^{29}$

\footnotetext{
${ }^{28}$ M. Sidi Ritaudin, Kalam: Journal of Religious Studies and Islamic Thought, State Radicalism and Power from a Global Political Perspective accessed March 25, 2021.

${ }^{29}$ Iman Fauzi Ghifari, Radicalism on the Internet, Religious: Journal of Religion and Cross Culture 1, 2 (March 2017) accessed Friday 02 April 2021
} 
Based on the description above, it is increasingly understood that in the context of global political thought, the double standard political reality of the United States (US) and its allies is the trigger axis that fuels the development of Islamic radicalism. ${ }^{30}$

Radicalism in this case is considered a foreign product and a global issue and its existence is widely associated with the religious understanding of Muslims, in other words radicalism is identified with Islam. There are various opinions related to the causes of radicalism, which can be seen as follows:

1. Social factors in the form of various cases of social, economic, and political inequality, are the main triggers that are used as tools for certain parties to arouse anger and feel they have been treated unfairly.

2. religious factors in the form of da'wah teachings, amar makruf nahi munkar and jihad, are used as legitimacy to carry out acts of radicalism in the name of religion. Religious teachings, which are actually neutral, have been interpreted exclusively by choosing only verses that connote violence and ignoring friendly verses.

3. Psychological factors, namely religious teachings that have been interpreted exclusively to fight injustice, are psychologically able to change views that were originally considered despicable (for example, killing and destroying) into a moral struggle. ${ }^{31}$

A similar opinion states that radicalism grows becauseThere are two fundamental factors, namely:

1. Economic deprivation and political injustice.

a. In the economic context, poverty encourages radicalism and terrorism due to prolonged frustration and economic inequality in society caused by the government's discriminatory policies.

b. In the political context, it is a form of protest by militant Islamic groups against the secular political system (democracy). The implementation of democracy has triggered militant Islamic groups to try to replace the existing political system with Islamic law. This group claims that Indonesia with a majority Muslim population in the world must implement an Islamic political system (Khilafah). On the other hand, democracy is considered unable to solve various problems such as poverty that remains rampant, society's morals are increasingly disorganized and so on.

2. Global injustice.

The US foreign policy (double standard) towards Islamic countries (middle east) caused a strong reaction from Indonesian militant Islamic groups against western countries (USA). This reaction in turn triggered militant Islamic groups to carry out acts of violence and threats of terror as their form of resistance. ${ }^{32}$

${ }^{30}$ M. Sidi Ritaudin, Kalam: Journal of Religious Studies and Islamic Thought, State Radicalism and Power from a Global Political Perspective accessed March 25, 2021.

${ }^{31}$ Nurjannah, Trigger Factors for the Emergence of Islamic Radicalism in the Name of Da'wah, Journal of Da'wah, Vol. XIV, No. 2 of 2013 accessed Thursday 1 April 2021.

${ }^{32}$ Supporting Factors of Radicalism and Terrorism in Indonesia.Pdf, accessed Thursday 01 April 2021. 
According to Afif Muhammad, the cause of radicalism is the powerlessness of religion to face the challenges of industry and globalization at the same timeThe uprooted element of motherhood (love, love, help) in religion is the result of the fierce currents of modernity. ${ }^{33}$ Different opinions were conveyed by Qardawi in Najahan Musyafak and Lulu Choirun Nisa regarding the causes and sources of radicalism, namely:

a. Half-hearted religious knowledge through a doctrinal learning process

b. Deep literal, understanding religious texts so that understanding of Islam only comes from the skin but lacks insight into the essence of religion.

c. Busy with secondary problems like growing beards and raising pants but forgetting about primary problems masalah

d. Excessive in forbidding many things that actually burden the people

e. Weak in historical and sociological insight, so their fatwas often contradict the problems of the people, common sense and the spirit of the times.

f. Reaction to other forms of radicalism such as secular radicals who reject religion

g. Resistance to social, economic and political injustice in the midst of society. ${ }^{34}$

Looking from a different perspective, Greg Fealy and Anthony Bubalo in this case convey their opinion that radicalism has a strong influence in the Middle East from the Muslim Brotherhood to Al-Qaeda and in Indonesia from reading books to internet publications. The importance of the internet as a tool for the transmission and dissemination of ideas The idea is especially strong among Indonesian salafi groups. Apart from their typical social conservatism, they use the internet because it offers an opportunity to create a de-culturated Islamic identity by creating websites www.salafi.net, www.salafipublications.com. ${ }^{35}$

Based on several descriptions of the opinions above, it is known and understood that the cause of the emergence of radicalism is due to several factors, namely social factors including economic and political factors, religious and psychological factors, these three factors are complemented by the presence of the internet which makes it easier for the issue of radicalism to spread among the public.

\section{B. Da'wah Solutions to Radicalism}

Da'wah is the pulse of Islam, through da'wah the teachings of Islam will spread to all corners of the world in realizing the mission of Islam as a mercy to the universe. According to Sampo Seha in Faridah, there are several targets in preaching which are divided into four types of targets, namely fardiyah or individual da'wah, da'wah to society or groups, social engineering da'wah and management of da'wah institutions. ${ }^{36}$

The duties and responsibilities of da'wah from time to time continue to increase along with the times. One of the tasks and responsibilities of Islamic da'wah today is to

${ }^{33}$ Iman Fauzi Ghifari, Radicalism on the Internet, Religious: Journal of Religion and Cross Culture 1, 2 (March 2017) accessed Friday 02 April 2021

${ }^{34}$ Najahan Musyafak and Lulu Choirun Nisa, Community Resilience Against Radicalism: Peaceful Action and Religious Conflict, Semarang; Lawwana, 2020, p.37.

${ }^{35}$ Iman Fauzi Ghifari, Radicalism on the Internet, Religious: Journal of Religion and Cross Culture 1, 2 (March 2017) accessed Friday 02 April 2021.

${ }^{36}$ Faridah, F. (2014). Da'wah Strategy in Spiritual Development of Prisoners at Class IIA Women's Correctional Institution Sungguminasa Gowa (Doctoral dissertation, Alauddin State Islamic University Makassar), p.77. 
stem and anticipate the notion of radicalism which seems to be increasingly spreading and disturbing various groups.

The solution of da'wah to the problems of contemporary people in this case is highly expected toremember that da'wah is a means to convey religious messages for mankind, the role of da'wah in this case is very important because the relationship between da'wah and religion is very close and the relationship created between humans as the target of da'wah and religion is a totality relationship and in essence religion does not inseparable from human life. However, because there is not only one religion adhered to by humans, then of course there will be conflicts that state the truth claims of each religion that is embraced by everyone. In fact, at the doctrinal level, all religions teach peace, brotherhood, and salvation. However, in the actualization of doctrine by religious adherents, there are often gaps that lead to conflicts leading to acts of radicalism. ${ }^{37}$

Responding to these problems, especially in Indonesia, where the condition of society is very heterogeneous, creates many issues related to the existence of radicalism among students and the community. Another thing not to loseConcerned is the moral condition that has become a social pathology in the community. ${ }^{38}$

Revelation Ilaihi and Harjani Hefni Polah in Faridah state that analyzing the condition of contemporary da'wah states that at this time the world actually has high hopes for Islamic da'wah. After the collapse of communism, contemporary society was almost destroyed by low morality and a large faction in the world power map. The existence of great interest in Islam by all people in the world is an important thing to get attention. This condition is a great opportunity for Muslims who are willing to work patiently and seriously in preaching. ${ }^{39}$

Sampo Seha in Faridah also added that there are five models of da'wah and this model can be a reference for contemporary da'wah models as a da'wah solution to overcome the problems of contemporary da'wah such as radicalism.

1. Da'wah in the guidance and counseling model, this da'wah is aimed at individuals who have problems or personal cases such as those who have experienced trauma and the like.

2. Da'wah is carried out in oral and written forms

3. Da'wah management is da'wah in the form of setting da'wah activities

4. Da'wah in the form of economic activity for the people, this da'wah aims to build people's passion to work optimally in realizing social welfare. ${ }^{40}$

The da'wah solution conveyed is in line with what was conveyed by Emha Ainun Nadjib who stated that the process of introducing Islam must be in an attractive way, the form of da'wah should be continuously reformed but not adapted to all the progress of the

\footnotetext{
${ }^{37}$ Angga Natalia, Factors Causing Radicalism in Religion (A Sociological Study of Religious Pluralism in Indonesia), Al-Adyan/Vol.XI, No.1/January-June/2016, Accessed Thursday 1 April 2021.

${ }^{38} \mathrm{Https}$ ://Journal.Uinsgd.Ac.Id/Index.Php/Anida/Article/View/5064, Accessed Friday 02 April 2021

${ }^{39}$ Faridah, The Urgency of Implementing Da'wah Strategies in the Contemporary Era, Pulpit Volume 2 Number 1, 2016, Accessed Friday 2 April 2021.

${ }^{40}$ Faridah, F. (2014). Da'wah Strategy in Spiritual Development of Prisoners at Class IIA Women's Correctional Institution Sungguminasa Gowa (Doctoral dissertation, Alauddin State Islamic University Makassar), h.56-57.
} 
times but still standing on the foundation of Islamic monotheism by modifying the expression - cultural expressions. ${ }^{41}$

In addition to the community, students who are also suspected of being a place for growth and development of radicalism, the steps that are considered appropriate to respond are to instill Islamic values among students, lecturers are required to explain verses of the Koran and hadiths related to the arguments for behavior. radical, so that students are better and display Islamic teachings that are friendly, tolerant, moderate, and do not pay attention to the harsh aspects of Islamic teachings. In addition, students are expected to practice the four pillars of nationality (Pancasila, the 1945 Constitution, Bhinneka Tunggal Ika, and the Unitary State of the Republic of Indonesia). Lecturers are expected to teach: directing, providing information, setting an example, educating, training, and guiding student behavior so that they have al-karimah character, faith, and piety to Allah SWT. ${ }^{42}$

The various explanations mentioned above provide a clear picture that radicalism can be overcome and minimized by cooperation between all elements of society, namely the government, preachers in the implementation of da'wah and lecturers (teachers) in the world of education. There are several efforts that can be done, namely:

1. Cool da'wah with the delivery of Islam comprehensively accompanied by example, the form of da'wah should be continuously reformed.

2. Islam appears in an interesting way, friendly, tolerant and moderate.

3. The practice of the four pillars of nationality (Pancasila, the 1945 Constitution, Bhinneka Tunggal Ika, and the Unitary State of the Republic of Indonesia).

4. The need to improve the quality of human resources through seminars, workshops, training, education and the like.

5. Equal distribution of justice and community welfare, one of which is through optimizing the function of the National Amil Zakat Agency (BAZNAS)

\section{CLOSING}

Da'wah is an Islamic communication that has several elements such as preachers, media (wash it), method (uslub) material (mawdu), target (mad'u) and purpose of da'wah. Radicalism in this case can be known, understood and analyzed from two perspectives, namely social and religious perspectives. From a social perspective, radicalism is considered as an understanding believed by individuals or groups who want to make fundamental changes to the prevailing social order by prioritizing confrontational attitudes. In the form of intimidation, suppression and violence. From an Islamic perspective, radicalism is an understanding based on fanatical ideological beliefs about the values they are fighting for to replace the existing values and systems with Islam in a formalistic manner and sometimes use violence to achieve their goals.

The cause of the emergence of radicalism is due to several factors, namely social factors including economic and political factors, religious factors and psychological factors, these three factors are complemented by the presence of the internet which makes the issue of radicalism easier to spread among the public.

\footnotetext{
${ }^{41}$ Asep Muhyidin And Agus Ahmad Safei, Methods of Da'wah Development, Bandung: Setia Pustaka, 2002, H.29.

${ }^{42}$ https://journal.uinsgd.ac.id/index.php/anida/article/view/5064, accessed Friday 02 April 2021.
} 
The da'wah solution to the problem of radicalism is cooperation between all elements of society, especially dai in the implementation of da'wah and lecturers (teachers) in the world of education are expected to be one of the solutions in dealing with the rampant behavior of radicalism. Da'wah that is displayed coolly with the delivery of Islam comprehensively accompanied by example, Islam must appear in an attractive way, friendly, tolerant, moderate the form of da'wah should be continuously reformed, the practice of the four pillars of nationality (Pancasila, the 1945 Constitution, Bhinneka Tunggal Ika, and the Unitary State of the Republic of Indonesia). In addition, it is necessary to improve the quality of human resources and equal distribution of justice for the entire community.

\section{BIBLIOGRAPHY}

Arifuddin Tike, $\quad \underline{\text { http://journal.uin-alauddin.ac.id/index.php/Al- }}$ Khitabah/article/view/2575, accessed Saturday 03 April 2021

Acep Aripudin, Development of Da'wah Methods, Jakarta: Rajagrafindo Persada, 2011, p.1.

Asep Muhyidin and Agus Ahmad Safei, Methods of Da'wah Development, Bandung: Setia Pustaka, 2002.

Angga Natalia, Factors Causing Radicalism in Religion (A Sociological Study of Religious Pluralism in Indonesia), Al-Adyan/Vol.XI, No.1/January-June/2016, Accessed Thursday 1 April 2021.

Faridah, F. (2014). Da'wah Strategy in Spiritual Development of Prisoners at Class IIA Women's Correctional Institution Sungguminasa Gowa (Doctoral dissertation, Alauddin State Islamic University Makassar).

-, F. (2015). Analysis of the Implementation of Dai's Example in the Effectiveness of Da'wah in the Contemporary Era. Journal of the pulpit: Muslim Intellectual Media and Spiritual Guidance, 1(1), 93109.https://doi.org/10.47435/mimbar.v1i1.272.

Firdaus Muhammad, Dean of FDK UIN Alauddin condemns acts of terrorism as well as being aware of the importance of religious moderation, SyiarMedia.id, accessed Thursday 1 April 2021.

Fatkhuri, Supporting Factors for the Formation of Radicalism and Terrorism in Indonesia,See discussions, stats, and author profiles for this publication at:https://www.researchgate.net/publication/318054171, accessed Thursday 01 April 2021.

Supporting Factors of Radicalism and Terrorism in Indonesia.Pdf, accessed Thursday 01 April 2021. 
Https://Journal.Uinsgd.Ac.Id/Index.Php/Anida/Article/View/5064, Accessed Friday 02 April 2021

Iman Fauzi Ghifari, Radicalism on the Internet, Religious: Journal of Religion and Cross Culture 1, 2 (March 2017) accessed Friday 02 April 2021.

Journal ADDIN, Vol. 10, No. 1, February 2016, accessed 1 April 2021.

Journal Selisik - Volume 2, Number 2, January 2016, accessed Thursday 01 April 2021.

Najahan Musyafak and Lulu Choirun Nisa, Community Resilience Against Radicalism: Peaceful Action and Religious Conflict, Semarang; Lawwana, 2020, p.37.

Nurjannah, Trigger Factors for the Emergence of Islamic Radicalism in the Name of Da'wah, Journal of Da'wah, Vol. XIV, No. 2 of 2013 accessed Thursday 1 April 2021.

M. Sidi Ritaudin, Kalam: Journal of Religious Studies and Islamic Thought, State Radicalism and Power from a Global Political Perspective accessed March 25, 2021.

Sindonews.com, Bomb Explosion at Makassar Cathedral, Observer: a message of solidarity with terrorist networks., accessed Thursday 1 April 2021

Suara jelata.com, Jokowi asks the National Police Chief to thoroughly investigate the network of suicide bombers in Makassar, accessed on Thursday 01 April 2021. 